\title{
Analysis on the Relationship Between Government and the Education Industry
}

\author{
Xiang Shu \\ Wuhan NO.6 High School, Hubei Province, 430000, China \\ Corresponding author. Email: gaoming@cas-harbour.org

\begin{abstract}
The relationship between government and the education industry has become more complex over time. The government should maintain a constant state of surveillance and intervene when appropriate. In this paper, the author talks about the function of government invention, how it works and how can it exert influence on the education. The author analyzed these questions through literature review. According to the research results, government intervention can effectively solve the problem of resource allocation, so that limited resources can be distributed more equitably. In addition, in the education market, government intervention can also effectively solve or prevent negative events, such as unhealthy competition or publicity, so as to maintain the healthy operation of the market.
\end{abstract}

Keywords: Education, Government intervention, market operation, equity

\section{INTRODUCTION}

Government intervention refers to the obligation of the government to participate in the formulation and implementation of policies to ensure the fairness and quality of the whole country and society [1]. One of the most persuasive reasons for government intervention in early education is equal opportunities in education, and there is growing evidence that schools may now find it difficult, if not impossible, to overcome the serious disadvantages of early childhood. In the real world, in many cases, the private market is unable to produce the best quantity of goods and services in society. The following essay will evaluate and compare the education industry with and without government intervention.

The government was accompanied by the beginning of human society. The existence of the government lies in the people. The Communist Party of China says that it is taken from the people and used to the people. If any government wants to survive, it has to collect taxes and money from the public. At the same time, the government is doing it for the country. Infrastructure, defense of the country, education, health care, culture, military, and so on all need to be developed. No one, no small organization, can do the above. This is the meaning of the existence of the government. Because of the meaning of this existence, the government also produces its own goals and corresponding powers and
obligations--Stability, freedom, security, equity, growth, efficiency.

In the following paper, the author will mainly talks about what functions the government has. Also, the author will take the education industry as an example to show what problems there will be in the market and how to solve them through government invention.

\section{FUNCTIONS OF GOVERNMENT INTERVENTION}

The government, which manages the country, is currently leading the country forward in most countries around the world [2]. Governments can sometimes improve market outcomes-government intervention. Without a government, this country, even if it is peaceful, will not go anywhere. Because no organization can be like a government. Even in modern civilization, resources are limited and human desires are infinite [2]. People are faced with trade-offs-choice, so war, competition, inevitable, need reasonable organization and distribution coordination. More efficient access to and use of development resources in the future will require scientific and technological progress and the need for countries. Only if the state provides all kinds of infrastructure and education, can there be more top talents, higher science and technology, better equipment, better life, and better life [3]. The government intervened in the market to solve the 
problem of inefficiency. In an efficient market, resources are perfectly allocated to those who need them. The Government is trying to eliminate these inequalities through regulation, taxation, and subsidies and to achieve the meaning and objectives of its existence.

The education industry can be taken as an example. Without the defects of government participation in the capital market, education in the education industry will become a private commodity, rather than a relatively public commodity in the Command Economy, in which the government is located, exclusive and non-competitive [5]. For example, the establishment of the 12-year Compulsory Education Law in the Chinese Government stipulates that people of this age need to go to school to receive education, which is an obligation for them to fulfill. Therefore, at this point, education can be obtained without paying money, and when people use it, people get a part of it, but it does not affect the education of others. For example, in a classroom, one more person in a classroom to listen to, a class or a class 40 minutes, or a teacher lecture, the content is the same, unless it is not a class, but a special one-on-one training class, so that you can only one-on-one class, and if you occupy the output of this teacher during this period time, other one-on-one students will not be able to take this teacher's class. This one-on-one ratio is expensive, namely, at least 400 yuan an hour. What is more, the class maybe only 400 in five classes. Not only does the number of students in class educate the price area of the commodity, but also according to the online and offline classes, some institutions are cheaper online than offline, because the offline need to occupy its limited classroom, have to pay for a range of costs involved in this class, including variable cost electric lights, projectors, computers generated by electricity bills, some institutions are cheaper than offline, because the offline needs to occupy its limited classroom, have to pay for a series of costs involved in this class, including variable cost electric lights, projectors, computers generated electricity bills. Whiteboard pens and other capital items, such as lights, computers, desks, stools, and so on, have been bought for a relatively long time, depending on the cost of increasing the cost of class hours and fixed ones. However, if people need these items online, but people do not have to provide them by themselves, students will stay at home and use them at home. If the teacher is also at home, the organization may be more cost-saving, so the supply curve will move to the right. As shown in figure 1, it moves from the S0 curve to the $\mathrm{S} 1$ curve, at which time, according to law of supply. In addition, as can be seen from figure 1 and figure 2, the equilibrium point moves from E1 to the relative horizontal and longitudinal coordinates of E2-the number increases from Q0 to Q1, and the price drops from $\mathrm{P} 0$ to $\mathrm{P} 1$.

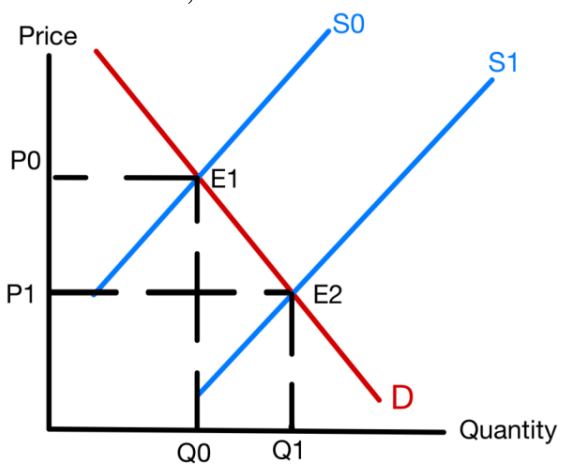

Figure 1. Relationship between price and quantity. 


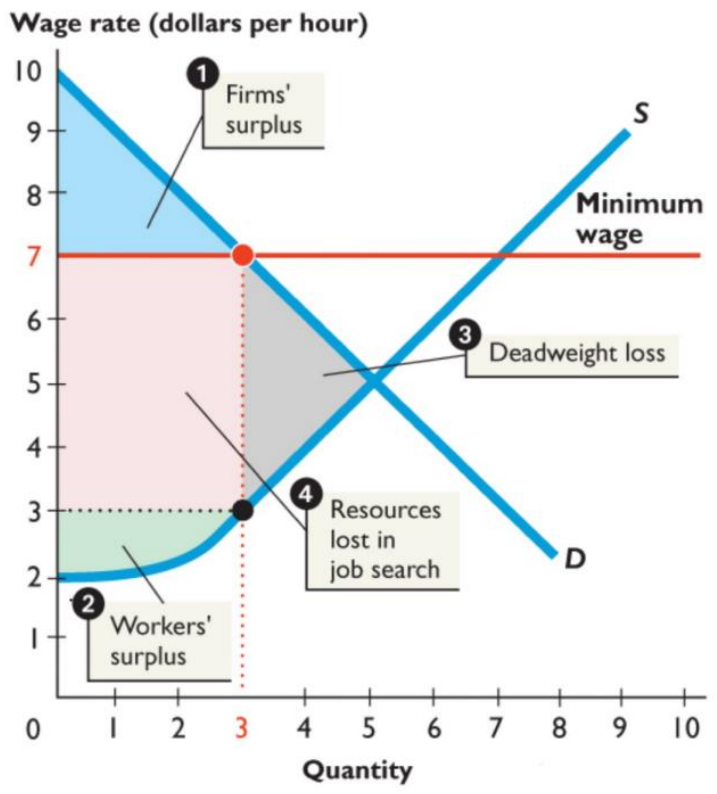

Figure 2. Influence of government invention on adjusting wage rate and quantity.

Similarly, if there is government intervention to stimulate, to provide subsidies, to lower corporate taxes to training institutions, or to give students' parents jobs [6]. To give indirect government intervention, the minimum salary capital should be set, because "people will respond to incentives" will also achieve the same effect as shown in figure 3. On the other hand, they can also be encouraged to set a minimum wage, subsidize their institutions, or lower taxes from the point of view of teaching staff, which will be more motivated to provide a better classroom and students can gain more content. However, because of some of the problems that may arise from the government mentioned earlier, Deadweight Loss can be seen on the chart.

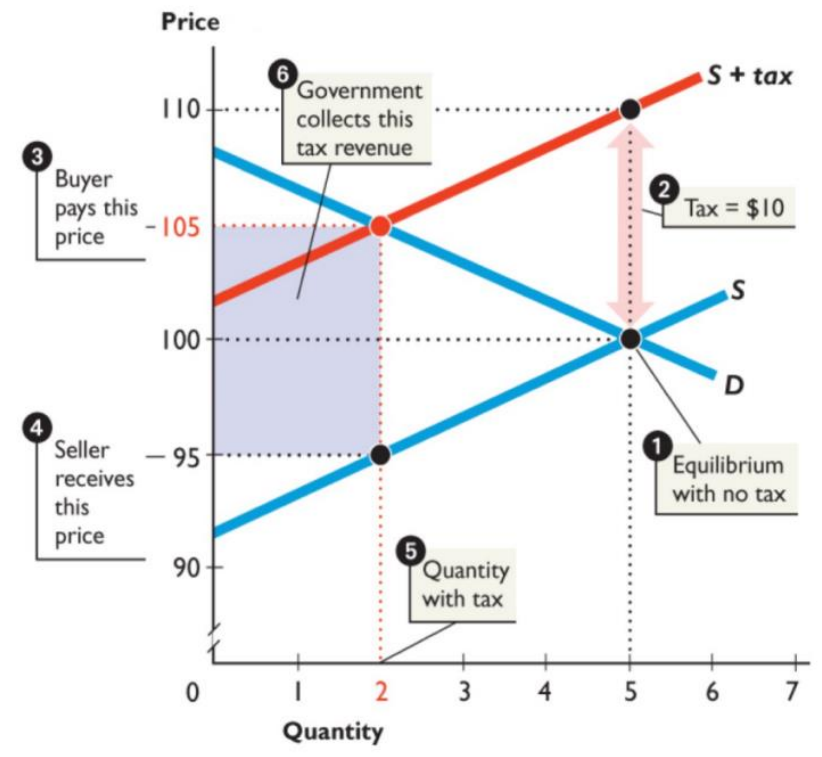

Figure 3. Influence of government invention on adjusting price and quantity.

All of these are government interference, so if there is no government intervention, there will be no subsidies, taxes, all have to rely on companies, consumers, employees, and invisible hands-price mechanisms for regulation and control. There will be no sudden temporary blockade of Covid-19 countries and cities to study vaccines, especially hospitals, medical schools, and universities, such as Oxford University, which have developed vaccines and praised them on the Queen's birthday, with 14 scholars awarded honors. If there is no government intervention, the infection cannot be excluded from effective treatment. For the education industry, such as teachers, students, parents, and so on, there will be no personal health guarantee. These have been issued by the government policies, issued instructions to develop in a good direction, and also 
targeted to put forward the A-LEVEL results of Teacher Assessment and non-submission of AS results of the new policy. Without government interference, there may be no way for the education industry to be protected by law, and teaching staff and some parents of dual workers may be particularly affected [4]. In addition, it has been argued that in the real world, in many cases, the private market is unable to produce the best quantity of goods and services in society.

Because education is a kind of merit goods, that the government should be responsible for managing and monitoring, it is the fiscal expenditure that the government must bear to collect people's taxes, and it is the obligation of the government. It should not interfere. Or maybe it is because this country is very backward, even food and clothing have not yet been solved, and the problem of food and clothing needs to be solved first, so education does not have enough experience and resources to interfere with, then the educational resources provided are very few, the education level of the whole country is low, and the gross national income (GNI) is also low because the total demand is local, the academic qualifications are not high, and there is not a lot of consumer expenditure. What is more, there will be crimes, so that there will be many factors of instability in the whole society. Referring to the table below, you can see that the top 10 are Korea, Russia, Canada, Japan, Ireland, Lithuania, Luxembourg, Australia, Switzerland, and the United Kingdom, all of which are relatively high levels of education and are among the most secure countries in the world to complete higher education between the ages of 25 and 34 .

\section{INFLUENTIAL FACTORS ON GOVERNMENT INTERVENTION}

However, because of Capital market defects, incomplete information, information asymmetry, externality, agency principle, fairness, education belongs to the merit goods, to plan and implement, and the government will be affected by these factors when it interferes with the education industry, resulting in unexpected bad results.

\section{CONCLUSION}

To sum up, education is a merit good, is the government's fiscal expenditure obligation, the government should do its best to improve its administrative efficiency, to avoid if the order is too slow to load to time lag or because of information problems leading to unintended consequences.

\section{AUTHORS' CONTRIBUTIONS}

The author finished this paper by herself. .

\section{REFERENCES}

[1] Fible

[2] Mankiw. Principles of Economics

[3] Joewongcomedy. (18 May 2021). Retrieved from: https://www.joewongcomedy.com/study-advice/wh at-is-the-argument-for-government-intervention-ineducation/ [Accessed 30 June 2021].

[4] UKEssays. (November 2018). Government Intervention in Education and the Environment. Retrieved from: https://www.ukessays.com/essays/politics/governm ent-intervention-education-5310.php?vref=1

[Accessed 30 June 2021].

[5] P. Wu, J. Lu. Income inequality and public policy intervention: education, medical care, urbanization. Copying newspaper materials: Public Management and Policy Review, 2015, 004(004): 64-77.

[6] T. Zhu. On the transformation of the concept of education equality and its realization path under the background of state intervention. Jinggangshan University Social Science Edition, 2013(01):65-70. 